\title{
Groundwater under stress: the importance of management
}

\author{
Henry Vaux
}

Received: 25 January 2010/Accepted: 5 February 2010/Published online: 24 February 2010

(c) The Author(s) 2010. This article is published with open access at Springerlink.com

\begin{abstract}
The most significant water problem facing the United States and the world is the scarcity of water. Scarcity is expected to intensify during the twenty-first century due to global population growth, economic growth and the need to protect environmental assets. In many regions, climate change may cause scarcity to become more acute. Groundwater has the capacity to buffer extreme hydrologic events because recharge is not directly tied to precipitation and run-off events. Groundwater storage offers many opportunities to increase storage and enhance the general water supply. The value of groundwater will increase as scarcity intensifies and effective groundwater management will be required if groundwater values are to be reaped. Effective groundwater management will require attention to certain well-established economic principles. Persistent overdraft is always self terminating. Individualistically competitive modes of extraction are inefficient. It is virtually always cheaper to prevent pollution in the first place than to remediate it. Groundwater management schemes appear to be most effective when they are locally developed and managed. Such schemes can regulate extractions and/or recharge either directly or indirectly. Evidence from the United States suggests that direct regulations can be made to work if they focus on recharge and developing supplementary sources of water. Evidence from South Asia suggests that regulation of extractions and provision of recharge water is most effective when indirect measures are used in which groundwater and ancillary variables such as electricity are co-managed. This evidence suggests that as supplementary sources of supply become scarce, innovative and indirect
\end{abstract}

H. Vaux $(\square)$

University of California, Berkeley, USA

e-mail: vaux0@att.net groundwater management schemes are likely to become more common.

Keywords Groundwater - Water scarcity · Management - Economics of groundwater . Management modes (USA and South Asia)

\section{Introduction}

In many regions and locales today, existing water supplies are already insufficient to meet urban, industrial, agricultural and environmental demands. The prospects of global population growth that will lead to an increase of approximately 3 billion by 2050 and the continued deterioration of water quality suggest that, even if everything else remains equal, water scarcity will intensify over the coming decades. The problem is likely to be magnified by virtue of the fact that much of the population growth will be in arid or semi-arid regions where potential evapotranspiration exceeds precipitation in most years. In these regions, which include the Savannah zones of the world, the availability of surface water is critically dependent upon the timing and magnitude of rainfall (Jury and Vaux 2005).

Concerns about the future adequacy of water supplies are not limited to arid and semiarid areas of the world. Although reductions in per capita use and increases in water use efficiency will help, projected increases in population and the resumption of economic growth will likely result in absolute increases in the demand for water for municipal and industrial uses. Likewise, the global demand for agricultural water will also increase as the world struggles to feed many more souls. The fact that irrigated agriculture is much more productive than rain-fed 
agriculture will help to fuel this increasing demand for agricultural water. Simultaneously, the need to define and identify adequate water supplies to support environmental uses will likely contribute further to the growing global demand for water. Indeed, the prospect of especially intense competition for supplies to serve agricultural and environmental uses will likely result in difficult choices with costly outcomes on both sides (Jury and Vaux 2007).

Water scarcity will extend to groundwater as well as surface water. Many of the world's aquifers are already persistently overdrafted. The growth of demand-particularly in areas where surface supplies are limited-and the continued deterioration of surface water quality will combine to place the world's groundwater resources under increasing stress. Groundwater resources will have to be managed in new and innovative ways to be successful in addressing the challenges that stem from this stress.

\section{The importance of groundwater in times of scarcity}

Aquifers and the water they contain are not simply one more source of supply. Both the water and the geological substrate in which it is stored have unique properties which will be especially important in a time of intensifying scarcity. Where aquifer recharge is significant and groundwater can be considered a renewable source of supply, the timing of recharge tends to be only indirectly related to the timing of precipitation and runoff. This means that groundwater often serves as a reliable source of supply during times of drought and shortage of surface water supplies. During times of drought groundwater can be extracted at rates greater than recharge on a temporary or intermittent basis and managed in ways that will allow the aquifer storage to recover following the drought. Thus, groundwater availability is not always tied to the timing of precipitation and run-off events as directly as is surface water.

The capacity of certain kinds of geologic formations to store water is also critically important. In many locales, the stock of stored groundwater far exceeds the existing and potential stock of stored surface water. For example, in the USA in the state of California, the stock of groundwater storage is estimated to be $1.06 \times 10^{12} \mathrm{~m}^{3}$, with perhaps half that susceptible to exploitation. Beyond that, groundwater storage capacity can be managed artificially to store additional supplies of water.

Aquifer storage offers promising possibilities for increasing storage capacity in water short regions while avoiding some of the pitfalls of surface water storage, including evaporative losses, sedimentation, land consumption, the high costs of civil works such as dams and adverse impacts on native populations and the environment.
Perhaps more importantly, the prospects for employing managed underground storage to take advantage of surface supplies in wet periods or supplies that become available from water reclamation and recycling projects have the potential to similarly augment supplies. Some techniques for managing aquifer storage, transfer and recovery result in improvements in water quality. Managed underground storage can be accomplished in ways that can augment reliable water supplies, often inexpensively (National Research Council 2008).

Since renewable supplies of groundwater tend to be more reliable than surface water supplies and groundwater storage affords the possibilities of enhancing the quantity and often the quality of available supplies, groundwater and groundwater formations are especially valuable in time of intensifying scarcity.

The value of these attributes is likely to be enhanced even more in an era of global climate change. Although much is still uncertain, there seems to be agreement that global warming may increase the frequency and severity of extreme weather events, both droughts and floods. It is also likely that changes in both the timing and magnitude of precipitation and runoff will not be favorable to many arid and semi-arid regions. Groundwater will become increasingly important as a buffering resource in the time of drought and as a resource that can be managed more intensively to enhance water availability and quality in a time of chronic and acute scarcity. In short, the prospect of global climate change simply enhances the value of groundwater. Management of groundwater resources in ways that will reap that value will require acknowledgment and understanding of several lessons from economics.

\section{Groundwater management: lessons from economics}

The economic principles of groundwater management are well developed. It is surprising, therefore, how frequently they are ignored. Yet, the lessons from economics become increasingly important as water scarcity intensifies. In considering these lessons it is important to remember that ground and surface water frequently interact. Failure to account for these interactions, including, natural discharges, can lead to invalid conclusions about what constitutes safe yield (Alley 2006; Glennon 2002).

Lesson 1: persistent overdraft is always self terminating

Overdraft is said to exist when the rates of extraction including natural extraction, if any, exceed the rates of recharge. Overdraft always leads to declining water table levels and such declines lead, in turn, to greater pumping depths. As water tables decline, a point is ultimately 
reached in which the costs of pumping from progressively greater depths exceed the benefits of any of the uses to which the water may be put. At this point, the aquifer is said to be economically exhausted. Economic exhaustion of renewable groundwater is rare. Nevertheless as water tables decline, some pumpers will find it no longer economical to continue extracting and will either stop extracting altogether or reduce the quantities extracted. This process continues until extractions and recharge are in equilibrium. There are at least two adverse consequences that follow. First, the amount of water extracted from the aquifer is reduced from the levels extracted during persistent overdraft. This means either that a supplemental source of water must be found or aggregate water use will have to be reduced. Second, the depth to the groundwater in the new steady-state equilibrium is greater than the optimal depth which means that henceforth the costs of extracting water will be greater than they would have been had the persistent overdraft not occurred.

There are several qualifiers to this lesson. Depending upon locale and the nature of the geological substrate, persistent overdrafting of aquifers can entail additional costs such as those associated with land subsidence and an increased risk of salt water intrusion in coastal areas. For aquifers with little or no recharge, overdraft is persistent by definition. The rule here is to withdraw the water so as to maximize the present net worth. The rules for optimal exploitation are the same as for any stock or nonrenewable resource. Intermittent overdrafting, such as may occur in response to a temporary drought situation is not always bad from an economic perspective. This conclusion is based on the proposition that intermittent overdrafting is punctuated by periods in which recharge exceeds extraction and the aquifer is allowed to recover.

Lesson 2: individualistically competitive exploitation results in extracting too much too soon

When a common pool aquifer with open access is exploited by many individuals in a competitive fashion, individual extractors have no incentive to account for the impact of their own extractions on others. This is because: (a) each individual believes her extractions to be so small relatively to all extractions as to have a negligible effect; and (b) restraints in extraction simply make the water not pumped available to competitors. In this way, users ignore the social cost of their extractions. The social cost is the cost on all other users of having to extract from a water table deeper than it would have been had the pumper in question not made the extraction. This social cost, known as the user cost, can be inflicted on all who extract from an aquifer to which there is open access. Optimal management of such aquifers requires incentives that will cause extractors to account for the social or user cost in arriving at pumping decisions.

The magnitude of the user cost depends on certain hydrogeologic characteristics of the aquifer. Other things being equal, the impact of one pumper's extractions on neighboring pumpers will be a function of the transmissivity of the aquifer. The higher the transmissivity, the higher the user cost. A related point is that the user cost will be dependent upon whether the aquifer is segmented or not; that is, whether there are zones where transmissivity is essentially zero and pumpers in one area experience no effect from extractions in adjacent areas.

Lesson 3: it is almost always cheaper to prevent pollution in the first place than to it is to remediate it once it occurs

This is especially true for groundwater. There is an abundance of evidence to support the proposition that remediation of water pollution is almost always more expensive than prevention. Groundwater cleanup tends to be especially expensive with pump and treat technologies being the only option in many instances and with the costs of such technologies being tied directly to the price of energy (Mackay and Cherry 1989; Abdalla 1990; National Research Council 1994). Despite the overwhelming evidence supporting this conclusion, groundwater quality protection plans have not always been successful. Past practices have left legacies of contaminants in the soil profile in virtually every region of the world. In these instances, prevention is no longer possible. Continuation of groundwater contamination globally in the future will be almost inevitable. Although improvements in remediation technology may help to lower costs, in the longer run the total cost of maintaining and enhancing groundwater quality will depend on developing effective schemes of preventing quality deterioration.

In a time of increasing scarcity, any scheme to manage groundwater resources responsibly and efficiently will acknowledge and incorporate these economic principles. Past groundwater management efforts have not always done so. The emphasis that ought to be given to such principles will depend in part on the hydrogeologic characteristics of the aquifer in question. The economic principles cannot be applied in anything but a blunt and clumsy way unless the underlying hydrologic and geologic properties are well understood.

\section{Institutions for groundwater management}

The evidence suggests that the most effective groundwater management institutions are those that are developed and 
managed locally. This is true in the United States, South Asia and elsewhere (Vaux 2007; Shah 2009). The preference for local institutions stems from the need for jurisdictions which coincide with the physical boundaries of the aquifer and the need to include all actors who have a clear interest in the water producing properties of the aquifer. In the United States, even where state and federal institutions are involved in groundwater management, those involvements tend to be indirect and limited to forums that modify, ratify and enforce arrangements that have been developed locally. The direct involvement of state government is not common, though Arizona is an exception. The federal government is largely absent from the groundwater scene. It has acted passively in the past by investing in water storage and conveyance facilities to augment groundwater recharge from surplus surface water supplies.

The recent history of groundwater use in South Asia is also illustrative because the resource is under intense pressure. Provision of water for irrigation and other purposes was a state and federal responsibility early on. In the last three decades there has been a dramatic shift in the water supply regimes away from state and federal canals to widespread groundwater pumping by individuals. Shah (2009) argues that this was the inevitable consequence of land scarcity and the need to farm available land as intensively as possible. Such intensive farming requires the availability of irrigation water on demand and only through the extraction of groundwater the multitude of small South Asia farmers could obtain water on demand. Today, the result is over 22 million groundwater extractors in India alone, most of whom behave in an atomistically competitive fashion. To the extent that cooperative behavior exists among extractors, it is organized and managed locally (Shah 2009).

To be effective, a groundwater management institution needs to have the capacity to regulate extractions or recharge or both. The regulation of recharge or extractions can be accomplished either directly or indirectly as a comparison of experience in South Asia and the United States shows. In the western United States early groundwater management efforts were limited to the development of additional supplies of surface water to offset groundwater overdraft. This technique was attractive because groundwater pumpers rarely paid anything like the full cost of the surface water supply and the effect was to subsidize overdraft to some extent. Cycles of overdraft followed by development of new supplies followed by a resumption of overdraft were repeated as many as three times (Vaux 1986). There are two shortcomings with this strategy. First, it leaves the groundwater vulnerable to additional overdraft by a new set of users. Second, it is not feasible in the absence of supplemental surface supplies. With more and more regions around the world becoming fully subscribed the availability of supplemental surface water will be seriously constrained in the future.

More focused institutional arrangements in the United States include those that are exclusively concerned with the acquisition and recharge of supplemental water supplies. Often such institutions take the form of user cooperatives. They have the advantage of a local perspective, they are capable of accounting for the hydrologic and geologic properties of the aquifer and they include all those with an interest in local groundwater productivity. There are examples of these kinds of arrangement in both the urban and agricultural sectors (Bloomquist 1992; Vaux 1986). In contrast, there are other arrangements that focus on restraining demand and augmenting supply. Typically these institutions regulate demand only indirectly through programs of education and the establishment of lose behavioral norms (Vaux 2007).

The common economic prescription for avoiding persistent overdraft and imposing the user cost on competitive pumpers is the pump tax. The tax is simply set equal to the marginal user cost and the extractor is billed periodically. Alternatively, pump quotas may be set in which each extractor is assigned an extraction quota which is enforced by water master or similar official. The problem with these regulatory mechanisms is that they entail large transactions costs. Meters are expensive. They must be accurate which requires maintenance and they must be read or recorded periodically. Effective enforcement entails further costs. As a general rule then, these measures are best suited to situations where there are few (usually large) extractors and the transactions costs can be minimized (Shah 2009). Demand management methods are well-known never-theless.

Direct regulation is not always workable. Shah describes in detail the political, social and cultural reasons why groups of atomistic extractors in South Asia cannot be regulated directly. These include high transactions costs, the imposition of large welfare losses on extractors who represent a significant political force and would resist any proposal which could have this result. Shah notes that Integrated Watershed Management schemes have not worked well in India precisely because they incorporate direct management instruments. As groundwater becomes more valuable, indirect means of management and regulation become more feasible than their direct counterparts (Shah 2009). This is a potentially significant finding because it suggests that the workability of indirect institutional means for managing groundwater may be determined more by the relative value of groundwater (a function of its scarcity) than by level of economic development in the country or region.

Devising effective schemes of indirect regulation requires an integrated, broad systems perspective on groundwater 
use. It requires innovative methods of solving groundwater depletion problems without directly touching their causes. Shah cites three examples from India. First, co-management of electricity and groundwater, where electricity is made available at times and rates which function as de facto regulation of groundwater. Second, use of dugwell recharge in hard rock aquifers, which has the advantage of being effective and inexpensive. A third and final example relates to the provision of inexpensive Chinese manufactured pumps which allow the agrarian poor in Bangladesh to maintain livelihoods based on groundwater. These examples illustrate, not just the importance of local schemes of groundwater management but the need for innovative management schemes which relay on ancillary variables to regulate and manage groundwater rather than attacking the rates of recharge and extraction directly (Shah 2009).

\section{Conclusions}

1. Water scarcity will intensify as population grows, while water quality declines; as demands for water usage grow, supplies will remain static or decline.

2. Groundwater will be uniquely attractive in an era of growing scarcity because it can be more reliable source of supply and because aquifer storage and treatment offer the opportunity to augment supplies.

3. The need to manage groundwater efficiently and effectively as its value increases requires management regimes that incorporate fundamental economic principles as well as detailed knowledge of the properties of the aquifer.

4. Most methods of groundwater management involve augmentation of recharge. This alternative will become less available as surface and groundwater scarcity grows. Experience in South Asia suggests that indirect methods of management and regulation are likely to be more effective as the value of groundwater grows. This suggests the possibility that as water scarcity intensifies, indirect means of managing groundwater will become more common in both the developed and developing world.

Open Access This article is distributed under the terms of the Creative Commons Attribution Noncommercial License which permits any noncommercial use, distribution, and reproduction in any medium, provided the original author(s) and source are credited.

\section{References}

Abdalla CW (1990) Measuring economics losses from ground water contamination: an investigation of household avoidance costs. Water Resour Bull 26(3):451-463

Alley WM (2006) Tracking U.S. groundwater reserves for the future. Environment 48(3):10-25

Bloomquist W (1992) Dividing the waters: governing groundwater in southern California. ICS Press, New York

Glennon R (2002) Groundwater follies. Island Press, Washington, DC

Jury WA, Vaux H Jr (2005) The role of science in solving the world's emerging water problems. Proc Natl Acad Sci 102(44):1571515720

Jury WA, Vaux HJ Jr (2007) The emerging global water crisis: managing scarcity and conflict between water users. Adv Agron 95:1-85

Mackay DM, Cherry JC (1989) Groundwater contamination: pump and treat remediation. Environ Sci Technol 23(6):630-636

National Research Council (1994) Ground water recharge using waters of impaired quality. National Academy Press, Washington, DC

National Research Council (2008) Prospects for managed underground storage of recoverable water. National Academy Press, Washington, DC, p 337

Shah T (2009) Taming the anarchy: groundwater governance in South Asia. RFF Press, Washington, DC, p 310

Vaux HJ Jr (1986) Water scarcity and gains from trade in Kern County, California. In: Frederick KD (ed) Scarce water and institutional change. Resources for the Future, Washington, DC

Vaux H Jr (2007) The economics of groundwater resources and the American experience. The global importance of groundwater in the 21 st century. In: Proceedings of the international symposium on groundwater sustainability, Alicante, Spain. National Ground Water Association Press, Westerville, pp 167-176 